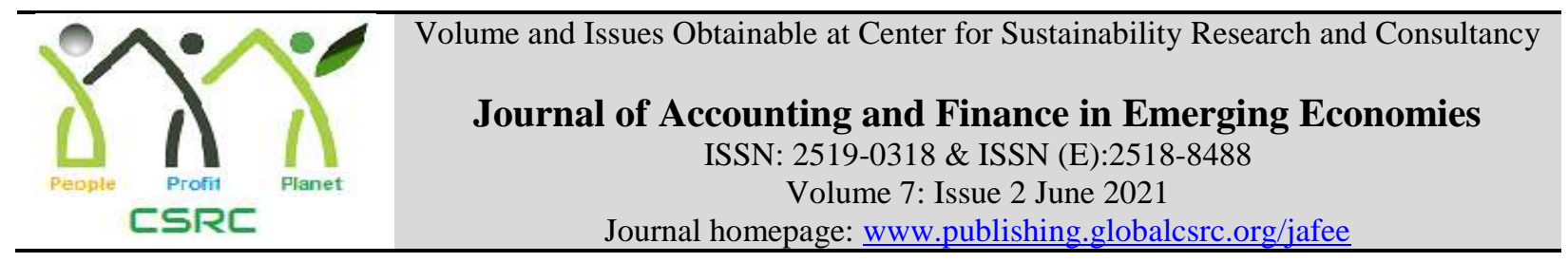

\title{
An Analytical Study of Conflicts and Violence on Socio-Economic Status in Pakistan
}

Hina Ali, Department of Economics, The Women University Multan, Pakistan

*Saeed Ur Rahman, Department of Economics, Ghazi University Dera Ghazi Khan, Pakistan

Farhana Nosheen, Department of Economics, Govt. Associate College for Women

Muzaffarabad, Multan, Pakistan

Iqra Ashraf, Department of History and Pakistan Studies, Women University Multan, Pakistan

*Corresponding Author email: srehman @ gudgk.edu.pk

\begin{tabular}{l}
\hline ARTICLE DETAILS \\
\hline History \\
Revised format: May 2021 \\
Available Online: Jun 2021 \\
\\
\hline Keywords \\
Economy, Society, \\
Violence, Conflicts, \\
Comparative Analysis \\
\hline
\end{tabular}

JEL Classification

A10, K14, P50

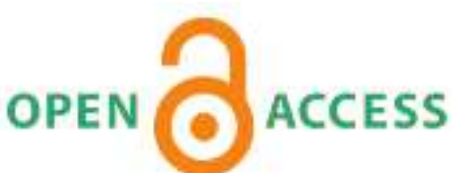

\section{ABSTRACT}

Purpose: This research focuses on how the currently occurring conflicts in Pakistan are leading to violent acts which in turn affect the society and the economy of the country. Conflicts and violence are becoming a colossal menace for developing countries such as Pakistan and Afghanistan. Design/Methodology/Approach: Moreover, the research has examined, using the tools of comparative analysis, how conflicts and violence affect the economy and society. Findings: The results suggest that conflicts and violence have rendered serious Socio-economic consequences. Conflicts and violence destroy assets, institutions and brutely disturb the social setup of the country by disturbing the socio-economic progress of the nation. Pakistan has been a victim of conflicts and violence since the day of its independence. Whether it is the migration of refugees in 1947, Pak Indo war of 1965, East Pakistan separation in 1971, post 9/11 war on terrorism, Lal Masjid attack in 2008, PNS Mehran terrorist attack in 2011, or the Peshawar Army Public School attack in 2015, Pakistan has suffered great losses both socially and economically. Implications/Originality/Value: The study has contributed towards better understanding of how conflice and violence has affected the socio-economic structure of Pakistan. Acid attacks, violence against women, child abuse, ethnic polarization, Islamic sectarianism, intolerance, and honor killings are a few of the many heinous acts that have not only affected each member of the society in Pakistan but have also proven to be a threat to each sector of its economy.

(C) 2021 The authors, under a Creative Commons AttributionNonCommercial 4.0

Recommended citation: Ali, H., Rehman, S., Nosheen, F. and Ashraf, I. (2021). An Analytical Study of Conflicts and Violence on Socio-Economic Status in Pakistan. Journal of Accounting and Finance in Emerging Economies, 7 (2), 357-364 


\section{Introduction}

History shows that economic stabilization is a source of prestige, power, and sustenance. And while on the other hand, economic power guarantees social protection and directs the sociopolitical aspects, while on the one hand, it has been used for exploitation and discrimination. This discrimination and disparities cause different kinds of disputes and lead society in an inert manner (Engels, 2004). Society and economy are the two major pillars that support the setup of any country. A country could be able to grow faster if its command regarding law-and-order conditions is very strong, this will automatically resultantly be boosting economic activities. Conflicts and violence are two monsters that eat up the society and economy of a country badly. Pakistan has always been a victim of various sorts of conflicts and violence ever since the day of its independence, but these activities become more common after the 9/11 incident in 2001. Conflicts kept on arising in the country due to ethnic sectarianism, religious differences, social backwardness, political inequality, and unlawful decisions by the judicial body of the country.

These conflicts resulted in violence in the form of kidnappings, gang rapes, murders, robbery, blasphemy, terrorist attacks, domestic protests, and many more heinous activities. So far, a total of 2, 62,522 people have become a victim of such activities in Pakistan. All these activities not only affect the victim directly but left a negative and long-lasting impact on the economy as well as the society of Pakistan. The wars impose enormous human, social and economic costs on the participating states. It is also true that wars, at the least, undermining the process of development. Despite the widespread recognition of these simple facts, there is remarkably little economic analysis of the effects of war and of what can be done to mitigate these effects. The typology of wars has been presented and the available information about some 16 countries' experience in dealing with the war is evaluated. The pathways by which the wars enforce costs can be found to identify certain policies and measures that can alleviate the economic effects. Feasible policies involve the intervention that helps to relieve the effect of war, like providing food and relief assistance to maintain social services, as well as those that reduce the long-term costs by, for instance, maintaining infrastructure. There are absolutely no simple solutions, although an economic analysis of wars can help in the planning of policies to decrease the developmental expenses associated with the wars. (Stewart, 1993).

Although terrorism does not appear to be a recent phenomenon yet the word for terrorism does not have a particular nor generally accepted definition (Jaspal, 2008). It is a multivariate and multidimensional phenomenon, present across the world. Developed countries would prevent less advanced or developing countries that are economical which leads to militancy in the form of a suicide bomb attack to accomplish their desired targets (Kazmi \& Parvez, 2011). About the role of Pakistan in supporting terrorist actions (Asal, Fair, \& Shellman, 2008) believe that this news, around the world, has increased momentum that Pakistan has been a center of anti-social and terrorist activities owing to its religion-political organization as well as geographical connections (Looney, 2004).

Collins (2002) looks at the concept of terrorism as 'Radicalism' like the group that provides support for radical change in a society that has faith in radical ideology. It is not a new trend and a phenomenon that can be traced back to thousands of years (Hoffman, 1999). Causational elements and the reasons for terrorism or extremism tend to change from time to time. Still, the usage and techniques are increasing in the direction of sophistication (Loza, 2009). Lutz and Lutz (2013) contend that changes that were made through globalization have led to the outbreak of political instability, involving terrorist actions, from a variety of groups. Therefore, Tocqueville, (cited in Brynjar \& Katja, 2000) said that social inequality is a major cause of terrorism in society. Likewise, research findings verify that (Mesoy, 2013) there is a causal relationship between poverty and radicalism/terrorism particularly in countries like Pakistan where because of poverty the young people joined the armed groups to earn handsome money. Additionally, 
another research project within the Swat Valley concluded that 63 percent of households accepted the fact that youth were joined the militant organization to improve their socio-economic status (Aziz, 2010).

\section{Objectives}

The objective of this study is to find out whether the conflicts and violent acts that have taken place in Pakistan in the last few years have affected the economy more or society. The following research questions shall be answered:

1) To what extent do conflicts and violence affect the economy of Pakistan?

2) To what extent do conflicts and violence affect the society of Pakistan?

3) Do conflicts and violence affect society more or the economy?

\section{Review of Literature}

A lot of studies have been done on the impact of conflicts and violence on the economy and the society of a country.

Alberto and Javier (2003) found out after thorough research that conflicts led to the downfall of the economy. Justino (2007) indicated that conflicts can have deep negative effects on human capital, and therefore suffering poverty and slow down the economic recovery. Martin, Mayer, and Thoenig (2008) figured out that the civil war had extensive and significant aggregate effects on macroeconomic indicators like the GDP and trade. Ksoll, Macchiavello, and Morjaria (2009) found out that differences in opinions and conflicts during the 2007 Kenyan presidential elections, the electoral violence reduced the labor force participation rate by $70 \%$.

Stewart and Fitzgerald (2010) stated that the countries that are a victim of conflicts and violence are more likely to turn away from educational and give up on employment and social activities. Robert et al. (2010) stated that together with the urgent physical and emotional effects of aggression, an individual's general quality of life may be negatively affected for a whole lifetime, which can, in turn, have an effect on their involvement and participation in different aspects of life and society. Siyan, Loayaza, and Reynal-Querol (2011) believed that civil conflicts tend to become more damaging to human resources, institutions, and social orders rather than large-scale wars.

Shemyakina and Olga (2011) believed because of the economic problems that are often accompanied by war, the poorest people in society might choose to take their children outside school so lowering the literacy rate. Lai and Thyne (2015) used cross country quantitative analyses to display that states in civil war experience a fall in enrolment by between 1.6 to 3.2 percentage points, which means a decrease of 64,000 students for a nation with a normally registered population of 4 million, thus reducing the literacy rate which in turn affect the society badly. Mueller, Piemontese, and Tapsoba (2016) were of the view that conflict can increase the risk perception of investors by increasing expectations about the potential for future outbreaks and instability thus affecting the economy badly. Overall, all the studies show that conflicts and violence do affect the economy or society badly, but no clear indications have been given as to which sector is affected more, the society or the economy.

Ljujic, Prooijen, and Weerman (2017) suggested a strong connection between unlawful offending and terrorism - the crime-terror nexus. Based on a strain theory perspective, undervalued socioeconomic status (i.e., limited education and joblessness) and criminal history specify the pool of people from where violent and terror criminals may be hired. The research contrasted three sources of data on educational and employment characteristics of violent and terror offenders: Dutch statistical data (CBS) including the Police Recognition System (HKS) on violent criminals, findings on jihadist networks, and open access on European terrorists. The 
majority of Dutch violent offenders, foreign fighters, and European terrorists had only completed secondary school (or lower) and were unemployed in the year of offending. Half of the recent European terrorists had previously been involved in violent crimes and/or had joined jihadi groups abroad.

Sardinha and Catalán (2018) utilized information from 49 Demographic and Health Surveys that were held between 2005 and 2017, United Nations Statistics, and topic-specific meta-databases. DV acceptance had been as measured by the excuse of "wife-beating for at least one of five circumstances, and by summative scale." Stepwise multiple linear regression analyzed countrylevel social, economic, and political empowerment forecasters of social acceptability of DV among the women, men, and the aggregate gender differential. The Conclusions underscored the need for tailored intervention measures targeting DV recognition within conflict-impacted societies. The primary focus of inter(national) policies concerning the 'empowerment' domains of commonly used gender (in)equality indices will have to be combined with strategies tackling discriminatory gender norms.

\section{Data, Data Sources, and Empirical Strategy Data Sources}

Data that has been used in this study is secondary data. Data from the year 2014 to 2018 has been used. For this study growth rate of GDP or Gross Domestic Product has been used as an economic indicator. On the other hand, literacy ratio and labor force participation in the country has been used as social indicators. Both economic and social indicators are the dependent variables. Statistics regarding GDP, literacy ratio, and labor force participation rate has been obtained from the Pakistan Bureau of Statistics and World Bank. Both economic and social indicators are the dependent variables. Data regarding the fatalities (independent variable) that occurred in Pakistan during various conflicts and violent attacks including terrorist activities, acid attacks, murders, etc., from the year 2014 to 2108 has been obtained from the South Asia Terrorism Portal and USA's Bureau of Diplomatic Security. Data regarding Pakistan's safety index and crime index has also been used to show the level of safety of Pakistan concerning the number of fatalities.

\section{Tools of Analysis}

Comparative analysis has been done to find out whether, in a year where the fatalities due to conflicts were high, the society was affected more or the economy. Trends of the number of fatalities have been compared with the up and down trends of the economic and social indicators to postulate a relationship amongst them.

\section{Results of the Study and Discussions}

Table 1 shows the crime index as well as the safety index of Pakistan from the year 2014 to 2018. The number of fatalities includes the deaths that resulted from terrorist attacks, murders, rapes, snatching, police encounters, kidnapping, etc. It shows the relationship between the crime index, safety index, and total fatalities.

Table 1: Crime index, Safety Index and No. of Fatalities in Pakistan (2014-18)

\begin{tabular}{|l|l|l|l|}
\hline Year & Crime Index & Safety Index & Total Fatalities \\
\hline $\mathbf{2 0 1 4}$ & 60.50 & 39.50 & 6584 \\
\hline $\mathbf{2 0 1 5}$ & 62.70 & 37.29 & 6850 \\
\hline $\mathbf{2 0 1 6}$ & 61.16 & 38.84 & 4822 \\
\hline $\mathbf{2 0 1 7}$ & 55.40 & 44.50 & 2941 \\
\hline $\mathbf{2 0 1 8}$ & 51.64 & 48.35 & 1357 \\
\hline
\end{tabular}


The higher is the crime index, the less safe the country is to live and vice versa. Moreover, a high crime rate results in a higher number of fatalities.

Table 2 shows the number of people who died from the year 2014 to 2018 in various conflicts and violent attacks and its impact on both the economic and social indicators used.

Table 2: GDP Growth Rate, Literacy Rate, Total Fatalities, Labor Force Participation Rate of Pakistan (201418)

\begin{tabular}{|l|l|l|l|l|}
\hline & & $\begin{array}{l}\text { Economic } \\
\text { Indicator }\end{array}$ & \multicolumn{2}{l|}{ Social Indicators } \\
\hline YEAR & Total Fatalities & $\begin{array}{l}\text { GDP } \\
\text { Growth Rate (\%) }\end{array}$ & $\begin{array}{l}\text { Literacy } \\
(\%)\end{array}$ & $\begin{array}{l}\text { Labor } \\
\text { Participation Rate (\%) }\end{array}$ \\
\hline $\mathbf{2 0 1 4}$ & 6584 & 4.4 & 60 & 53.90 \\
\hline $\mathbf{2 0 1 5}$ & 6850 & 4.2 & 58 & 53.72 \\
\hline $\mathbf{2 0 1 6}$ & 4822 & 4.8 & 56 & 53.91 \\
\hline $\mathbf{2 0 1 7}$ & 2941 & 5.74 & 58 & 54.09 \\
\hline $\begin{array}{l}\mathbf{2 0 1 8}\left(\text { As on } 8^{\text {th }}\right. \\
\text { October 2018) }\end{array}$ & 1357 & 5.97 & 57 & \\
\hline
\end{tabular}

The data from table 2 has been shown in graphical form in figure 1 and figure 2 . Figure 1 shows the impact of fatalities on the economy for which the growth rate of GDP which is the economic indicator that has been used. The reason for using the growth rate of GDP as an economic indicator is that it shows the economic growth rate, and one objective of this study is to find out the impact of conflicts and violence on the economic development of the country.

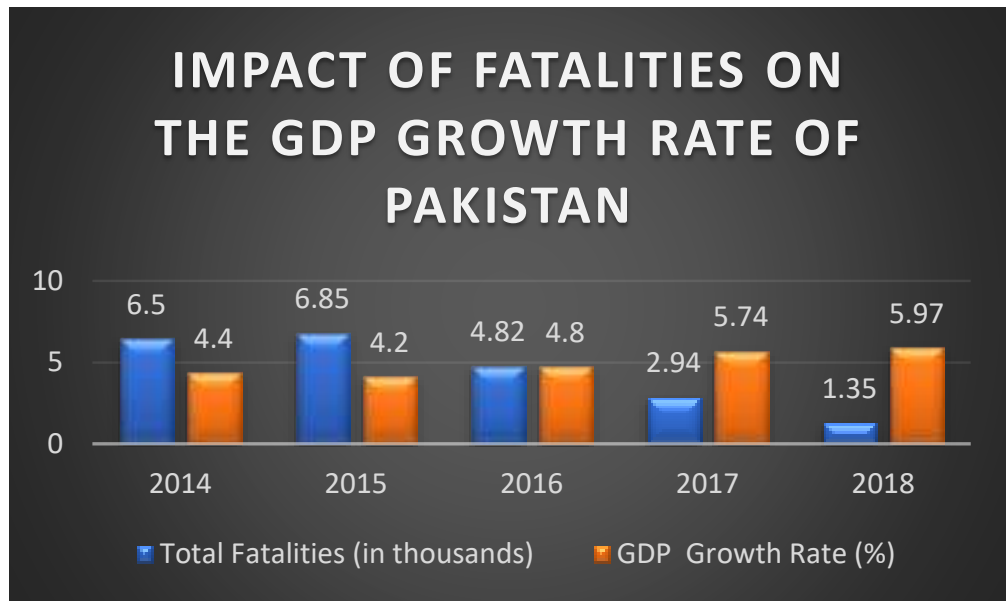

Figure 1: Impact of Fatalities on the GDP Growth Rate of Pakistan (2014-18)

Figure 2, on the other hand, shows the impact of fatalities on the society for which literacy rate and Labor force participation rate have been used as the social indicators.

Following are the reasons for choosing these two variables as the social indicators:

i) The higher the literacy rate, the better the standard of the society

ii) The higher the labor participation rate, the safer people feel living in society.

A higher percentage of both these variables show that the members of the society have strong faith in the social set up of the country, therefore they prefer to get the education and chose to look for jobs in their home country rather than moving to abroad or sitting at home due to a sense of insecurity and fear of being killed. 


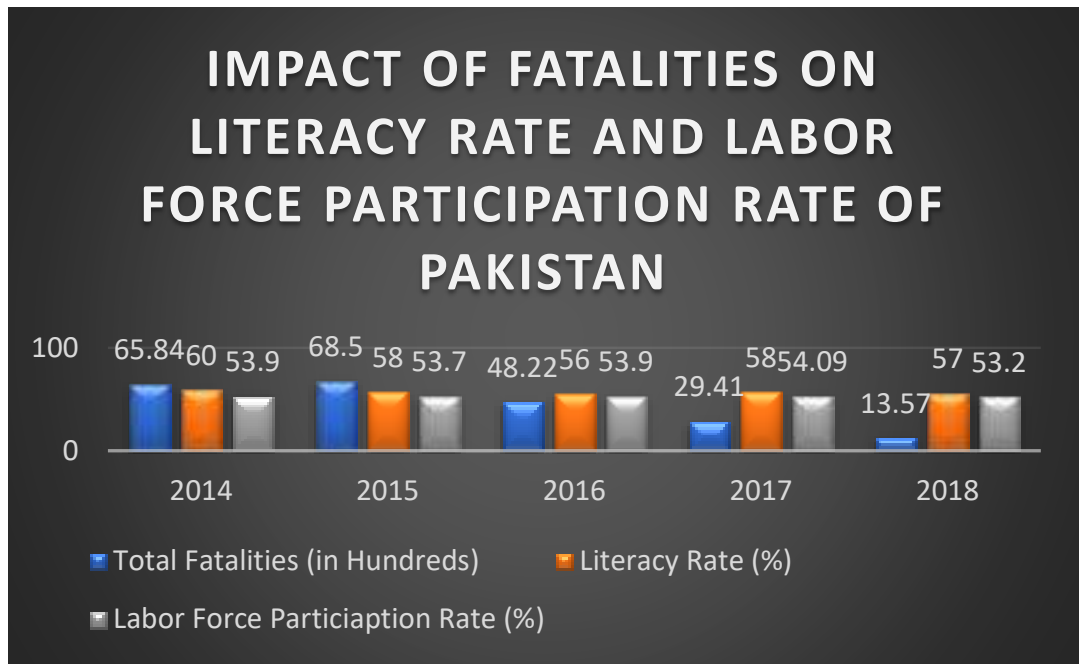

Figure 2: Impact of Fatalities on Literacy Rate and Labor Force Participation Rate of Pakistan (2014-18)

\section{Discussion and Conclusion}

It can be seen in table 1 that the higher the crime index in the country, the higher is the number of fatalities and the less safe the country is. From the year 2014-18, the crime rate kept on increasing and so did the number of casualties. During the year 2016-17, the crime index showed a sharp decrease and so did the number of fatalities.

Table 2 incorporates total fatalities with the growth rate of GDP as the economic indicator and literacy rate and labor force participation rate as the social indicators. The data from table 2 have been shown in figure 1 and figure 2 . Figure 1 clearly shows that there exists a negative association between the number of fatalities and the GDP growth rate. The higher the number of fatalities, the lower is the growth rate of GDP in the country. In the years 2014-18 when the number of fatalities increased, the GDP decreased, and when afterward the number of fatalities showed a sharp decline in the growth rate of GDP rose drastically. This shows that conflicts and violence do have a direct and immediate effect on the economy of the country.

This happens because of the following reasons:

1) The higher rate of conflicts and violence makes the investment climate of a country unfavorable thus affecting the GDP of the country negatively.

2) A higher number of fatalities result in loss of human capital, which in turn results in reducing the GDP of the country.

3) An unfavorable investment climate results in the devaluation of money, negative balance of payments and trade, thus making the GDP negative.

4) Pakistanis tend to invest their money in foreign countries rather than their home country because of the insecurity that exists because of various sorts of conflicts.

5) Violent activities harm the assets of the country and the domestic industry badly.

These are many of the few reasons how conflicts and violence badly affect the economy. Next, it has been examined whether conflicts and violence have an impact on society or not. As shown by previous studies, there is no denying that all sorts of conflicts and violence do affect society but here the question is whether it affects society more or the economy. Figure 2 shows that in the years 2014-18 when the country becomes a little safer, the literacy rate increased as more people chose to step out of their homes to get an education. The labor force participation rate also increased as Pakistan became safer to work in.

On the other hand, from 2016 onwards the fatalities in Pakistan reduced drastically, which means Pakistan became a safer country, as the safety index increased sharply. The social indicators 
didn't respond immediately to these positive changes. Instead, the literacy rate remained the same in 2017 as it was in 2015, whereas there was a huge difference in the number of fatalities in 2016 and 2017. In 2018, when the number of fatalities reduced, even more, the literacy rate reduced instead of increasing. The labor force participation rate was also reduced.

This shows that to some extent the conflicts and violence do affect society but:

1) society doesn't respond as quickly to conflicts as the economy does.

2) the impact of conflicts is more evident and extreme on the economy than they are on the society

Another important point to notice is that the impact of conflicts and violence on the society eventually affect the economy in the end because as the social indicators such as labor force and literacy rate show a downward trend, the human capital available to the economy also reduces which eventually results in the downfall of the economy.

\section{Conclusion}

Terrorism is an illegitimate and unlawful use of force by an individual or a group of persons against persons to pressurize, threaten leadership or societies generally for their political and ideological objectives. The main target of the terror campaign is to get power. Brutality and aggression, to accomplish the evil goal, play an important part. These devices will be used to creating terror in the minds of the masses. Terrorist, at the same time, has a destructive intention to hurt the image of the government by providing an image to the citizens that it has not yet been able to ensure peace and security as well as has no right hold on to power. Previous studies have shown that conflicts and violence affect both the economy and the society in Pakistan, but the extent of the impact has so far been ignored. This research paper has made an addition to the previous studies by showing that the impact of conflicts and violence is more evident in the economy than it is on society. Thus, the two concluding statements of this paper are:

1. "Conflicts and violence have a more prominent and an immediate effect on the economy of Pakistan than on its society."

2. "The impact of conflicts and violence on the society is eventually manifested on the economy".

\section{References}

Alberto Abdie \& Javier Gardeazabal (2003). The Economic Costs of Conflict: A Case Study of the Basque Country. The American Economic Review, Vol. 93, No. 1., pp. 113-132.

Asal, V., Fair, C. C., \& Shellman, S. (2008). "Consenting to a Child's Decision to join a Jihad: Insights from a Survey of Militant Families in Pakistan. Studies in Conflict and Terrorism, 31(11), 1001-1022.

Aziz, Khalid (2010). The main causes of the breakdown of Governance and then rise of militancy. Retrieved from

Brynjar, L., \& Katja H-W, S. (2000). Why terrorism occurs - A survey of theories and hypotheses FFI/Rapport-2000/02769 Norway, Forsvarets Forsknings Institute Norwegian Defense Research Establishment, NO-2027 Kjeller.

Collier, P.; Hoeffler, A. \& Soderblom, M. (2004). 'On the Duration of Civil War'. Journal of Peace Research 41.3. pp. 253-73.

Collins Thesaurus of the English Language, Complete and Unabridged 2nd Edition (2002). http://www.thefreedictionary.com/radicalism Accessed: 05/01/2013 11:15 PM

Engels, F. (2004). Origin of the Family, Private Property, and the State. International Resistance Books, 23 Abercrombie St, Chippendale NSW 2008, Australia.

Hoffman, B. (1999). Inside Terrorism. New York: Columbia University Press pp.86- 129. Retrieved from: http://www.jstor.org/discover/10.2307/20049971 ?uid=3738832\&uid=2\&u $\mathrm{id}=4 \&$ sid $=21102784722933$. 
Jaspal, Z (2008). WMD Terrorism and Pakistan: Counterterrorism Defense against Terrorism Review Vol. 1, (No. 2).

Justino, P. (2007). 'A Micro-Level Analysis of Poverty and Conflict Traps'. IDS Working Paper 385. Harvard University. Vol .3.

Kazmi, S. F., Parvez, T. (2011). "Socio-Economic and Cultural Perspectives of Terrorism in Pakistan and the Madrassa (Mosque) Students". International Journal of Academic Re s e a r c h. Volume 3, Numb e r 2. Re tri e v e d www.ijar.lit.az/en.php?go

Lai, B., \& Thyne, C. (2015). The effect of civil war on education. Journal of Peace Research, 277-292.

Ljujic, V., van Prooijen, J. W., \& Weerman, F. (2017). Beyond the crime-terror nexus: socioeconomic status, violent crimes, and terrorism. Journal of Criminological Research, Policy and Practice.

Looney, R. (2004). "Failed economic Take-offs and Terrorism in Pakistan”. Asian Survey, 44(6), 771-793.

Loza, W. (2009). "Letter from the Chair, CPA Section on Extremism/ Terrorism. 1, (1)", Retrieved, May 7, 2013, from http://www.prosocialscience. org/ Extremism201 (1).

Lutz, J \& Lutz, B. (2013). The Role of Foreign Influences in Early Terrorism: Examples and implications for understanding modern terrorism. Perspective on terrorism Volume 7, (No 2). Retrieved from: http://www.terrorismanalysts.com/pt/index.php/pot/article/view/252

Martin, P., Mayer, T. \& Thoenig, M. (2008). 'Civil wars and international trade. Journal of the European Economic Association. Vol. 3.

Mesoy, A. (2013). NOREF Expert Analysis: Poverty and radicalization into violent extremism, a causal link. Norwegian Peace Building Resource Centre. Retrieved from http://www.isn.ethz.ch/Digital-Library/Publications/ Detail/?lng=en\&id=158431.

Mueller, H., Piemontese, L. \& Tapsoba (2016). Recovery from Conflict: Lessons of Success. World Bank Policy Research Working Paper, forthcoming.

Robert D. Abbott, Ick-Joong Chung, JieGuo, J. David Hawkins, Todd I. Herrenkohl \& Karl G. Hill (2010). Protective Factors against Serious Violent Behavior in Adolescence: A Prospective Study of Aggressive Children. Journal article by Social Work Research, Vol. 27.

Sardinha, L., \& Catalán, H. E. N. (2018). Attitudes towards domestic violence in 49 low-and middle-income countries: A gendered analysis of prevalence and country-level correlates. PloS one, 13(10), e0206101.

Shemyakina \& Olga (2011). "The effect of armed conflict on the accumulation of schooling: Results from Tajikistan”. Journal of Development Economics, Elsevier, vol. 95(2), pp. 186-200.

Siyan, C., Loayaza, N. \& Reynal-Querol, (2011). 'The Aftermath of Civil War'. World Bank Economic Review.

Stewart F, \& Fitzgerald V. (2010). War and underdevelopment: the economic and social consequences of conflict. Oxford: Oxford University Press. 